\title{
Towards a Sound Performance Appraisal System: An Agenda for Action
}

\author{
Prof. (Dr.) H.H.D.N.P. Opatha \\ Senior Professor \\ Department of Human Resource Management \\ University of Sri Jayewardenepura
}

\begin{abstract}
This paper is an attempt to present a synthesis with regard to Performance Appraisal (PA) by utilizing significantly the author's previous published works which are based on theoretical as well as empirical studies done so far in the area of PA. The paper has its focus on utility of $P A$ including the possible reasons for not having an effective high quality PA system in most of the organizations in Sri Lanka, an agenda for action, and a model of PA interview.
\end{abstract}

Key Words: Performance Appraisal, Feedback, Interview

\section{Background}

Being a developing country Sri Lanka is in serious need of a performance culture of excellence in every organization as her socio-economic development heavily depends on success and performance of organizations for which PA is a sine qua non. PA is concerned with identifying, measuring, influencing and developing job performance of employees. There is perhaps not a more important human resources system in organisations than performance appraisal and supervisors' ratings of subordinates' performance represent critical decisions that are key influences on a variety of subsequent human resources actions and outcomes (Judge and Ferris, 1993).

Literature on Performance Management (PM) presents two meanings to the term Performance Management. First meaning is that PM is an alternative term to Performance Evaluation or PA. For example, according to Stewart and Brown (2009), $\mathrm{PM}$ is the process of measuring and providing feedback about employee contributions to the organization. Lepak and Gowan (2010) define PM as the process of: (1) evaluating employee performance against the standards set for them and (2) helping them develop action plans to improve their performance. Second meaning is that PM is a broader concept that stresses establishing objectives based on strategic goals of the organization, employee feedback, coaching for employee development and appraisal (Aguinis, 2007). In view of Mathis and Jackson (2009), PM is a series of activities designed to ensure that the organization gets the performance it needs from its employees and performance appraisal is the process of determining how well employees do their job relative to a standard and communicating that information to the employee. According to them, PM involves a series of activities leading to achieving organizational performance through employees and PA is a part of PM. Indeed PA is in PM. However PM is broader than PA. PA is an integral part of PM and indeed the heart of PM is PA. In other words the essence of PM is PA. 


\section{Utility of PA}

PA measures how well and how far employees are performing their jobs within the period being considered for enhancing human performance (self and others) and business performance of the organization. The impact of PA on human development and institutional development has been theoretically and empirically well established. A recent study (Ali and Opatha, 2008) in Sri Lanka showed a significant and positive relationship between perceived systematic use of PA system and perceived degree of business performance of apparel firms in Sri Lanka. The relationship found was strong (correlation coefficient was .826 that was significant at .0005) implying that an apparel firm, though it is large or non-large, should adopt a more systematic PA system so as to improve its business performance.

PA is expected to provide answers to many of the questions in respect of people management in organizations. It has a variety of utility and serves as a summative function (to assist in making equitable and effective personnel decisions); a formative function (to improve employee current and future performance); and an informative function (a communication to the employee dealing with upward and downward communication for self development) (Opatha, 2009 ${ }^{1}$ ). Ideally a good PA system can be used to achieve at least administrative purposes that include: (1) To grant salary/wage increment; (2) To select employees to be promoted; (3) To determine the gravity of disciplinary actions; (4) To terminate/confirm employment; (5) To validate selection tools; and (6) To reward employees (other than salary/wage increments and promotions) and development purposes that include: (1) To ascertain potential performance and development needs of the employee so as to develop him/her; (2)To identify training needs of each employee so as to improve each employee's job performance; (3)To counsel employee; and (4)To assess results of training programs.

Studies pertaining to practice of PA in Sri Lankan organisations (Opatha, 1992, Opatha, 2003 ${ }^{1}$, Opatha, $2003^{2}$, Opatha, 2005) reveal a significant gap between what should exist and what in fact is existing. One study was an empirical study, a formal personnel audit effort which dealt with an assessment of employee PA practices of four selected state corporations in Sri Lanka. This study attempted to explore and describe the PA practices in the selected corporations and to assess PA practices in the light of theoretical formulations and comment on major defects in PA in the selected corporations. Synthesis of the literature of theoretical arguments and research resulted in formation of an assessment framework of ideal PA system which was an original contribution to the body of knowledge.

The framework was composed of elements such as objectives, policies on PA, PA criteria, method, feedback interview, appraiser training, and procedure for ensuring accurate implementation and review and renewal. Summary of assessment indicated that systematic use of PA practices in cases A, B, and D was very low and in the case of $\mathrm{C}$ was also low implying that current PA practices and systems must be revised or new PA systems are to be introduced for better performance management. Another empirical study of PA Systems being followed by five public quoted manufacturing firms revealed that the degrees of systematic utilization/quality of PA systems in three firms (A, C, and D) were moderate and those of PA systems in two firms (B and E) were low as per 5-point scale suggesting significant revisions to be made to the PA systems so as to improve them. Observational studies reveal that some organisations were not serious about PA, some did not do PA as planned and others faced various 
problems of ineffective PA systems. Another recent study (Opatha, 2011) revealed that there was statistical evidence to claim that the degree of systematic use of Human Resources Management practices of multinational firms including PA is significantly different from that of local firms; In fact the degree of systematic use of Human Resource Management practices of multinational firms including PA was greater than that of local firms. However, none of the firms had a PA system whose quality level was very high. Dimensions and elements of employee PA which were derived from conceptualization and operationalization for this study are shown in Figure: 1 given at the end of the paper.

What are the possible reasons for not having an effective high quality PA system in most of the organizations in Sri Lanka? Possible reasons are:

1. It seems that responsible managers do not believe that PA is a driver of job performance and business performance and it has a variety of utility. In fact they do not have the right attitude about PA.

2. Some organizations have a culture that is not valuing excellence at work. Majority of employees are moderate in terms of job performance and having a fear and a dislike to get their job performance evaluated. Also they have reluctance to see that few employees are excellent at work and are better than them owing to jealousy and inability to face competition.

3. Line managers in some organizations do not take PA as a serious method as it has no link with rewards and training and development.

4. The PA system has been introduced in some organizations as a human resource management programme, not as a general management programme initiated by the top management (not merely by Human Resource Department). Also doing PA has not been specified as an essential duty of job descriptions given to managers.

5. In some cases, there is no objective high quality PA system developed due to lack of expertise in PA and HRM.

There is a strongly felt need for developing an effective PA system and implement it in a planned way. A central question in this context is how to develop a good PA system and implement it as planned. PA is perceived as a systematic process which is composed of ten steps such as establishment of PA objectives; formulation of policies; establishment of PA criteria and standards; selection of method(s); design of forms and procedures; training of evaluators; appraisal in action; discussion of PA results; making decisions and storing; and finally review and renewal (Opatha, 2002, Opatha, 2009). Figure: 2 presents the PA process. 
Figure: 2 Process of PA

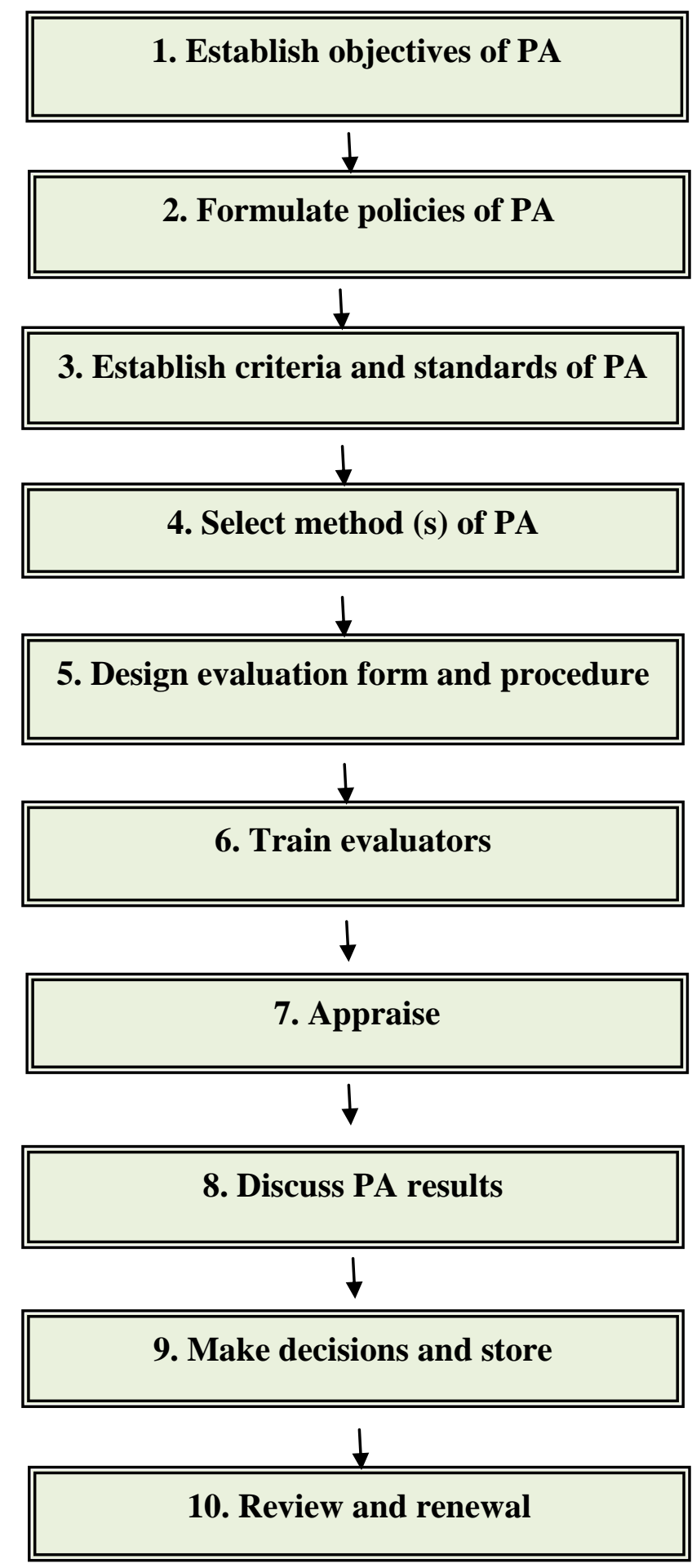

Source: Opatha, 2002, Opatha, $2009^{2}$

\section{Towards an Agenda for Action}

Essentially, as an agenda for action a 20-Point-Programme (adapted from Mithani and Opatha, 2000) is envisaged, thus: 
1. Spell out very clearly all the objectives of PA.

2. Make all the employees (evaluees and evaluators) known about the objectives of their PA so as to develop a right attitude within all concerned.

3. Evaluate formally all the employees (casual, temporary and permanent) so as to maximise realization of all the possible purposes of PA.

4. Apply Fixed Time Approach instead of Arbitrary Time Approach for the issue of 'When'. Use Job Cycle Approach whenever possible.

5. Combine several parties to do PA of an employee including immediate superior. Use of 360-degree feedback is desired.

6. Conduct PA at least twice a year because of the reasons of lesser possibility of occurrence of "Recency Effect" and greater opportunity of giving feedback to the person being evaluated.

7. Follow the principle of Multiplicity and establish PA criteria to measure traits (qualities), behaviours (activities, actions) and results (outputs). However, greater weightage is to be given to results, as they are the most important at the final analysis.

8. Define all the criteria unambiguously so that the user can understand them properly.

9. Adopt procedures so as to make all the criteria more objective (enhancing qualitative measurability and verifiability).

10. Apply systematic and fair rating scales (degrees of success such as excellent, good, average, poor and very poor). Standard of excellence should challenge the employee while being realistic (setting an extremely high standard to motivate employees to perform at their maximum level may backfire).

11. Have rating scales between five and nine so as to improve consistency among evaluators as well as the reliability of PA.

12. Apply the method of Graphic Rating Scales (GRS) for measuring traits, the method of Behaviour Observation Scales (BOS) for measuring behaviours, and the method of Management By Objectives (MBO) for assessing results.

13. Design separate PA forms and procedures for different categories of employees so as to improve the principle of Relevance.

14. Train evaluators and evaluees in respect of the PA systems by following a model of training that consists of training objectives, evaluator manual, formal instruction and on-the-job coaching \& counselling.

15. Follow strategies such as recognising and rewarding the evaluator for accurate appraisal; making PA as an important duty in the Job Description of the evaluator; introducing the PA system as a management programme initiated by top management not as a Human Resource Management programme; and considering duty of doing PA about subordinates as a criterion or a subcriterion when evaluating job performance of the superior.

16. Ensure that relevant evaluators keep records of performance of subordinates throughout the evaluation period.

17. Establish the practice that after PA, the evaluators always discuss with the employee through feedback interviews.

18. Apply Mixed II (Tell-and-Listen and Problem Solving) in giving feedback.

19. Make relevant decisions based on PA results of relevant employees. Linking PA with rewards (pay, financial and non-financial incentives, etc) and training and development is a must.

20. Perform review (systematically to find out whether the PA system is being carried out in the planned way and to determine improvements for more 
successful system) and renewal (to make needed revisions to the PA system according to the results of review so as to keep it dynamically alive and productive).

Point 17 was Establish the practice that after PA, the evaluators always discuss with the employee through feedback interviews. Unfortunately this requirement being done in high intensity is almost non-existent in Sri Lankan organizations, particularly in the public sector. One integral part of any performance appraisal system is the performance appraisal interview (Nemeroff and Cosentino, 1979) and which is a performance review session giving the evaluee a feedback in respect of his/her past performance assessed and improvement of future performance. This interview is a significant part of any PE system and it should focus on the job performance of the employee evaluated.

The interview allows the evaluator to communicate the evaluee's ratings and to comment on them with proper justifications. It also enables the evaluee to know the degree of his / her performance as per the criteria set by the evaluator and ways and means of improving his / her performance. Feedback, which is the extent to which knowledge of results concerning individual effectiveness and efficiency is provided, is one of the five core job dimensions of the Job Characteristics Model of Motivation proposed by Hackmon and Oldham. According to the model, satisfaction and motivation are controlled by the three critical psychological states: meaningfulness of the work, responsibility for the outcomes of work and knowledge of the results of work (Dale and Cooper, 1992). Feedback gives knowledge of the results of work and that is given through PE interview.

During a PE interview alternatively called performance review meeting, there are two roles, i.e. judge and coach to be played by the evaluator. As a judge the evaluator does evaluation of the employee's job performance for the relevant period of time and recommend appropriate rewards. As a coach the evaluator assists the employee to identify performance-related problems and design a plan for his/her self development. Indeed to play these two roles successfully is a challenge. However, one can enjoy performing this task if the evaluator is appropriately skillful at the roles.

If the PA interview is handled improperly, it can lead to creating unfavorable feelings such as anger, disappointment, resentment and despair instead of giving feedback for improving performance and personal development. Supervisors are often unprepared to conduct appraisals and seldom possess the effective interviewing skills vital to this process (Edwards and Williams, 1998). See Figure: 3 which depicts a model of PA interview process along with a set of important guidelines to any manager who is supposed to undertake PA discussion. 
Figure: 3 A Model of PA Interview Process

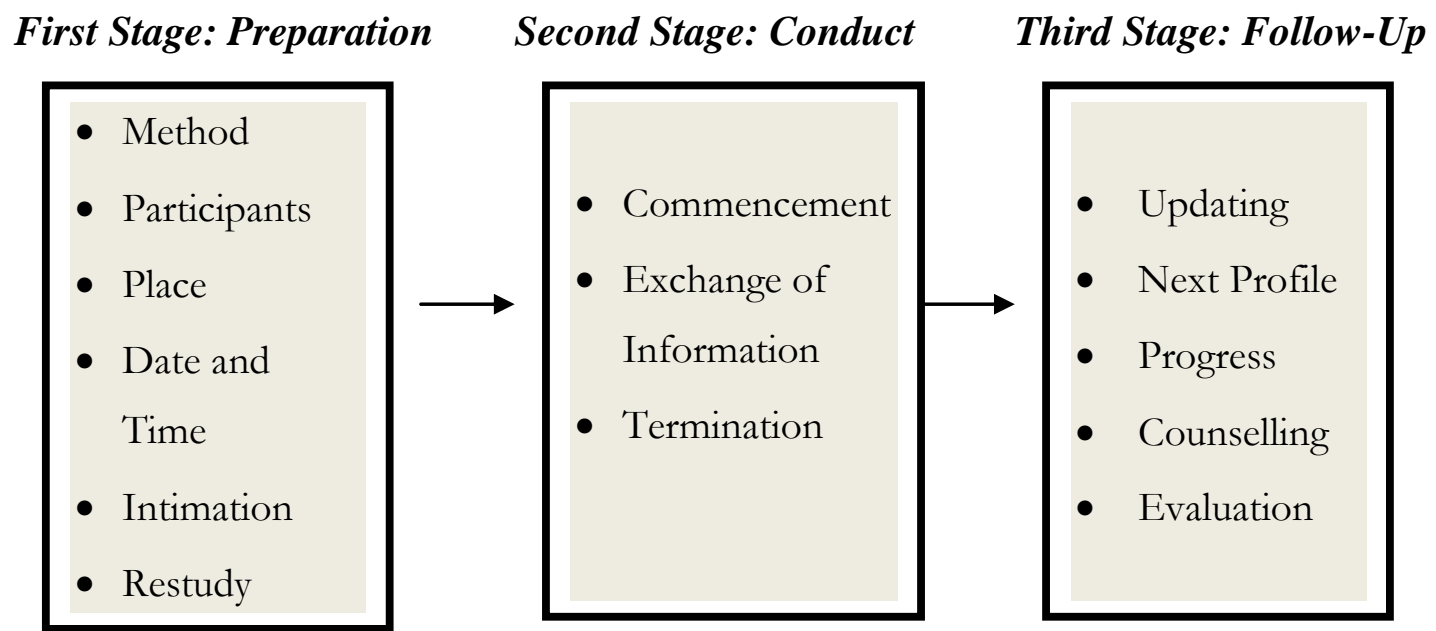

\section{Preparation}

The amount of thought and preparation employees independently devote before the interview increases the benefits of the interview (Rue and Byars, 1992). Preparation stage is planning for the interview which consists of the following elements:

\section{Method}

There are several types of interviews such as tell-and-sell (the evaluator tells the degree to which the evaluee has performed the job during the period of PA and sells $\mathrm{him} / \mathrm{her}$ steps to be taken for improvement where the evaluee has limited chance to participate in the discussion); tell-and-listen (the evaluator communicates the evaluee about the degree of job performance and weaknesses and strengths and lets the evaluee respond to those); problem-solving (special problems being faced by the evaluee relating to job performance are identified and an attempt is made mutually by the evaluator and the evaluee to find out solutions for those problems); and mixed (either combination of tell-and-sell and problem-solving or combination of tell-andlisten and problem-solving). It is suggested to use the mixed type (tell-and-listen and problem-solving) in order to maximize advantages and minimize disadvantages of both methods.

\section{Participants}

Essentially the evaluator and the evaluee should participate in the interview. If there is more than one evaluator, ideally all evaluators should participate in the exercise. Then all can contribute to the act of giving feedback to the evaluee for improving performance and personal development. If there are immediate superior of the evaluee and superior of the immediate superior participating in the PA interview it encourages a genuine discussion.

\section{Place}

A right place needs to be decided for the discussion. Here right means private and comfortable. A neutral location (neither the evaluator's nor the evaluee's work place) should be selected so that both the evaluator and the evaluee can meet privately and in 
quiet surroundings by avoiding interruptions. Hindering behaviours such as signing letters, answering telephone calls and talking to others during the conversation need to be avoided for successful discussion. Selection of a right place will help to have a better discussion free of hindering behaviours.

\section{Date and Time}

Selecting a date and a time, which are convenient to both the evaluator and evaluee, is necessary. It is not appropriate to decide the holding of the interview at a time when either evaluator or evaluee is likely to be under stress or tiredness. Mornings may be better. It is better to allow plenty of time for the interview. When the time affects as a major constraint, at least one hour should be allowed. If possible, schedule the PA interview so that the evaluator and the evaluee agree upon an appropriate date and time.

\section{Intimation}

To inform the evaluee about the interview sufficiently in advance is a good practice because it gives time for the evaluee to prepare for the interview. A copy of the completed evaluation form can be given to the evaluee in advance enabling to save time and hold a more candid discussion.

\section{Re-study}

The evaluator must prepare for the interview by restudying the job and all the relevant records of the evaluee. The objective is to be specific and justify adequately each rating given. Also reviewing the evaluee's qualifications, previous experience, previous performance evaluations and plans will also be helpful for a successful interview. The evaluator should prepare notes on areas of training/development which may assist the evaluee. If the evaluee has already been given a number of constant negative evaluations disciplinary actions may have to be considered according to the rules and regulations of the organization. Following seven questions are to be answered prior to the performance appraisal interview recommended by Rue and Byars (2004):

1. What are the specific good points on which you will compliment the employee?

2. What are the specific improvement points you intend to discuss?

3. What reactions do you anticipate? How do you intend to handle these reactions?

4. Can you support your performance appraisal with adequate facts?

5. What specific help or corrective action do you anticipate offering?

6. What is your approach for gaining acceptance of your suggested corrective action?

7. What follow-up action do you have in mind?

\section{Conduct}

Having prepared for the PA interview, the next step is to conduct the interview in reality. This stage involves the following elements.

\section{Commencement}

To start the interview at the scheduled time with a proper salutation is needed. Also putting the evaluee at ease will be helpful for successful discussion. Here needs 
establishment of 'rapport', which means harmonious and understanding relationship between the evaluator and the evaluee. A smile, a handshake and a relaxed posture will help establish the rapport. It is important to stress that the purpose of the interview is to improve employee's performance and not to enforce discipline. The evaluator should describe the purpose and intended outcome of the interview briefly. Importance of obtaining feedback by the evaluee needs to be stressed especially when the employee is new to this exercise.

\section{Exchange of Information}

The exchange of information on the evaluation is the heart of the process. This element ensures two-way communication between the evaluator and the evaluee. The evaluator should not dominate the discussion. Of course he/she should take the lead in the interview but the evaluee should be encouraged to talk. The more employees are allowed to voice their opinions during the interview, the more satisfied they feel with the interview (Rue and Byars, 1992). Review should be an exchange of information and the goal is to get employees to do more talking and thinking about their performance (Farr, 1998).

If the evaluee's performance is outstanding, make that known at once because the evaluee will move readily to accept any suggestion or minor criticism (Donnelly, et al., 1984). If the evaluee's overall performance is unsatisfactory, evaluator should avoid discussing it at the beginning. One way to discuss is to highlight a specific positive aspect of the performance and then get down to negative aspects. Another approach is to ask the evaluee to give his/her perception about his/her own performance and then reveal the evaluator's perception about the evaluee's performance. If the evaluee does not bring up areas of unsatisfactory performance, the evaluator must do so.

In this context it is possible to do self-appraisal (PA done by the employee in a copy of the form provided by the evaluator). This requires the evaluator to let the employee present his/her ratings first. Kirkpatrick (1982) and Aguinis (2007) present following guidelines in this regard:

1. The evaluator should listen to what the employee has to say and summarize what he hears. This is not an appropriate time for the evaluator to disagree with what the employee says.

2. Next the evaluator should explain the rating he/she has provided for each performance dimension and explains the reasons the rating led to each score.

3. It is good to start with a discussion of the performance dimensions or criteria for which there is agreement between the employee's self-appraisal and the evaluator's evaluation. Likely this reduces tension and to demonstrate to the employee that there is common ground and that the PA meeting is not confrontational. It is better to start with a discussion of the performance criteria for which the scores are highest and then move on to the criteria for which the scores are lower.

4. For criteria for which there is disagreement between self appraisal and evaluator's evaluation, the evaluator must take great care in discussing the reason for his/her rating and provide specific examples and evidence to support the score given. 
5. For a very useful discussion to lead to clarify performance expectations, provide the employee with the opportunity to explain his/her viewpoint thoroughly.

6. For criteria for which the scores are low, a discussion of possible causes such as lack of competence, lack of self-confidence, lack of motivation, and contextual factors beyond the control of the employee must be done. This is useful for the employee's development and the organizational success.

It is very important to be specific rather than being general and vague when making criticisms. Criticism should be focused on performance, not personality characteristics of the employee. Arguing with the evaluee should be avoided as much as possible because arguing implies that the person who argues is correct and the other one is incorrect. The evaluator should identify, show and explain actions that can be taken by the evaluee to maintain or improve or correct performance. Both the evaluator and the evaluee should agree upon actions (future plans). The evaluator's willingness to assist the evaluee's efforts and to improve performance should be emphasized (Werther et al., 1985).

Dessler (1984) stresses that manager should make sure to develop an action plan, work with the person to set improvement goals that are specific and practical, along with a timetable for achieving them. Here, it is usually best to focus on the two or three most important areas in which you want improvement rather than on all the areas identified in the evaluation.

\section{Personal Development Plan}

This plan specifies areas in need of improvement and courses of action to be taken for the purpose of development of the employee whose performance has been evaluated. It directs the employee to do better in the future by avoiding performance problems faced in the past. Following questions need to be addressed to prepare a good personal development plan:

- What are the weaknesses or areas of improvement? Answer should identify employee development needs (these can be framed as development objectives).

- How can these weaknesses be avoided or what are the actions for areas of improvement? Answer should propose strategies to meet employee development needs.

- What are the resources and/or support needed by the employee to implement strategies? Answers should list resources and/or types of support to be provided by the organization.

- When should employee development needs be met? Answers should include a time frame for achieving development objectives/needs.

- How to know whether the accomplishment/meeting of each development objective/need is done or not? Answers should contain specifics of measuring degree of achievement of development objectives/needs.

Strategies to meet development needs can be referred to as development activities and they include on-the-job-training, workshops, specialized courses offered by professional institutes and universities, general courses, self-guided reading resources, attending a conference, reading for a diploma or a degree, mentoring, job rotation, 
temporary work assignments, membership or leadership role in professional organizations, distance learning program, making seminars, and participating in seminars. List is not final and there may be other options such as appointment on acting basis. A separate section in the PA form can be created for this personal development plan. A section as shown in Exhibit: 1 can be developed for the purpose. Exhibit: 2 presents an example of a personal development plan for a Production Supervisor in a textile manufacturing firm.

Exhibit: 1 A Format of a Personal Development Plan

\section{SECTION III PERSONAL DEVELOPMENT PLAN}

Please complete each of the following section as specific as possible.

\begin{tabular}{||l|l|l|l|l|}
\hline $\begin{array}{l}\text { Development } \\
\text { Needs }\end{array}$ & $\begin{array}{l}\text { Development } \\
\text { Strategy/Strategies }\end{array}$ & $\begin{array}{l}\text { Needed } \\
\text { Resources } \\
\text { /Support }\end{array}$ & $\begin{array}{l}\text { Time } \\
\text { Frame }\end{array}$ & $\begin{array}{l}\text { Evaluation of } \\
\text { Meeting } \\
\text { /Achievement }\end{array}$ \\
\hline & & & & \\
\hline & & & & \\
\hline & & & & \\
\hline & & & & \\
\hline & & & & \\
\hline
\end{tabular}

Any other comments you wish to make:

Exhibit: 2 An Example of a Personal Development Plan

\section{SECTION III PERSONAL DEVELOPMENT PLAN}

Please complete each of the following section as specific as possible.

\begin{tabular}{|c|c|c|c|c|}
\hline $\begin{array}{l}\text { Development } \\
\text { Needs }\end{array}$ & $\begin{array}{l}\text { Development } \\
\text { Strategy/Strategies }\end{array}$ & $\begin{array}{l}\text { Needed } \\
\text { Resources } \\
\text { /Support } \\
\end{array}$ & $\begin{array}{l}\text { Time } \\
\text { Frame }\end{array}$ & $\begin{array}{l}\text { Evaluation of } \\
\text { Meeting } \\
\text { /Achievement }\end{array}$ \\
\hline $\begin{array}{l}\text { 1. Right attitude } \\
\text { about people at } \\
\text { work }\end{array}$ & Workshop & $\begin{array}{l}\text { Two hours } \\
\text { Self-evaluation } \\
\text { checklist } \\
\text { File, pen and five } \\
\text { sheets }\end{array}$ & $\begin{array}{l}\text { To be } \\
\text { completed } \\
\text { by the end } \\
\text { of next } \\
\text { month } \\
\text { (January) }\end{array}$ & $\begin{array}{l}\text { Full } \\
\text { participation }\end{array}$ \\
\hline $\begin{array}{l}\text { 2. Knowledge } \\
\text { about } \\
\text { employee } \\
\text { services }\end{array}$ & $\begin{array}{l}\text { Special in- house } \\
\text { course }\end{array}$ & $\begin{array}{l}\text { Two days } \\
\text { Reading material } \\
\text { Stationeries }\end{array}$ & $\begin{array}{l}\text { Course to be } \\
\text { completed } \\
\text { by March, } \\
31^{\text {st }} 2010\end{array}$ & $\begin{array}{l}\text { Marks } \\
\text { secured from } \\
\text { a multiple- } \\
\text { choice } \\
\text { questions } \\
\text { paper } \\
\end{array}$ \\
\hline $\begin{array}{l}\text { 3. Skill in } \\
\text { communicating } \\
\text { with people }\end{array}$ & $\begin{array}{l}\text { Special one day- } \\
\text { course offered by a } \\
\text { consultant }\end{array}$ & $\begin{array}{l}\text { One day } \\
\text { Course material } \\
\text { Stationeries } \\
\text { Reimbursement } \\
\text { for the course }\end{array}$ & $\begin{array}{l}\text { Course to be } \\
\text { completed } \\
\text { by the end } \\
\text { of June, } \\
2010\end{array}$ & $\begin{array}{l}\text { Full } \\
\text { participation } \\
\text { and grade } \\
\text { given by the } \\
\text { consultant for } \\
\text { applications }\end{array}$ \\
\hline
\end{tabular}

Any other comments you wish to make: The employee has a high degree of motivation to learn. Has a good self awareness of his areas of improvements. 
After clarifying what was intended to cover and ascertaining that the evaluee has had a chance to review the issues, the evaluator should draw the interview to a close. To do a summary of what has been discussed and agreed is suggested. This summary should be given positively and enthusiastically. The part of the evaluation form for giving comments and signature of the evaluee should also be completed at this point. The purpose of this requirement is to ensure that the evaluee should know what has been given about his/her performance and should be encouraged to give his/her comments/disagreements/views on PA. Also it is important to express thank and appreciation for the evaluee's participation from the point of human relations.

\section{Follow - Up}

After conducting the PA interview the evaluator should do several activities, which include updating the evaluee's personal file with all the information regarding present period's performance and action plans agreed to; beginning the next period's PA profile with a summary of the present report and any plans; watching the evaluee's progress and initiating informal progress reviews; and counselling and giving advice as necessary. As an activity of post-interview, Morrisey (1983) proposes to evaluate how the evaluator has handled the discussion by raising questions regarding how well the evaluator has done it, what aspects he/she did poorly, how he/she could have done better, and what he/she could learn about the employee (evaluee) and the jobs. Right answers for these questions will be useful for the evaluator to do the next interview better.

Is it possible to make PA strategic? Yes. Making PA strategic involves two things: emphasizing either merit-based systems or parity-based systems and linking merit and parity systems to HR strategy (Stewart and Brown, 2009). Merit-based system is a PA system that specifically seeks to identify and recognize the contributions of high performers and Parity-based system is a PA system that seeks to recognize contributions from all employees (adapted from Stewart and Brown, 2009).

Exhibit:3 A Comparison between Merit-based System and Parity-based System

\begin{tabular}{|l|l|l|}
\hline Aspect & Merit-based system & Parity-based system \\
\hline $\begin{array}{l}\text { Basic } \\
\text { objective }\end{array}$ & $\begin{array}{l}\text { Create and recognize high } \\
\text { performance in order to achieve } \\
\text { superior outcomes. Underlying } \\
\text { purpose is to encourage } \\
\text { employees to perform at the } \\
\text { highest possible level. } \\
\text { Employees who produce the } \\
\text { highest outcomes or results are } \\
\text { given high marks. }\end{array}$ & $\begin{array}{l}\text { Encourage cooperation and } \\
\text { allow everyone who meets a } \\
\text { certain standard to be classified } \\
\text { as a high performer. }\end{array}$ \\
\hline $\begin{array}{l}\text { Frequent focus } \\
\text { On outcomes or results rather } \\
\text { than traits and processes. }\end{array}$ & $\begin{array}{l}\text { On processes rather than } \\
\text { outcomes or results. }\end{array}$ \\
\hline $\begin{array}{l}\text { Definition of } \\
\text { high } \\
\text { performance at } \\
\text { work }\end{array}$ & $\begin{array}{l}\text { Not just as meeting certain } \\
\text { standard but as doing better than } \\
\text { others. }\end{array}$ & $\begin{array}{l}\text { Following guidelines and } \\
\text { performing behaviors assigned } \\
\text { by supervisors. }\end{array}$ \\
\hline
\end{tabular}




\begin{tabular}{|c|c|c|}
\hline $\begin{array}{l}\text { Usually done } \\
\text { through the } \\
\text { use of }\end{array}$ & $\begin{array}{l}\text { Relative measures which are } \\
\text { performance ratings that assess } \\
\text { an employee's contributions } \\
\text { through comparison with the } \\
\text { contributions of other } \\
\text { employees. }\end{array}$ & $\begin{array}{l}\text { Absolute measures which are } \\
\text { performance ratings that assess } \\
\text { an employee's contribution in } \\
\text { comparison to a fixed standard } \\
\text { or benchmark. }\end{array}$ \\
\hline $\begin{array}{l}\text { Most systems } \\
\text { adopt }\end{array}$ & $\begin{array}{l}\text { Forced distribution which has } \\
\text { performance ratings that spread } \\
\text { out ratings by requiring raters to } \\
\text { place a certain percentage of } \\
\text { employees in each category; } \\
\text { grading on the curve-e.g. placing } \\
20 \text { percent of employees in the } \\
\text { top category, } 70 \text { percent in a } \\
\text { middle category, and } 10 \text { percent } \\
\text { in a category of low } \\
\text { performance. }\end{array}$ & $\begin{array}{l}\text { Free distribution which has } \\
\text { performance ratings that allow } \\
\text { raters to place as many } \\
\text { employees as they wish into } \\
\text { each rating category. E.g. any } \\
\text { employee who assembles a } \\
\text { certain number of cell phones } \\
\text { without error can be given a top } \\
\text { performance rating, regardless } \\
\text { how many cell phones others } \\
\text { assemble. }\end{array}$ \\
\hline $\begin{array}{l}\text { Possibility of } \\
\text { becoming a } \\
\text { top performer }\end{array}$ & $\begin{array}{l}\text { Not possible for every one; only } \\
10 \% \text { or } 20 \% \text { or a few. }\end{array}$ & $\begin{array}{l}\text { Every employee can be a top } \\
\text { performer. }\end{array}$ \\
\hline Separation & $\begin{array}{l}\text { Does separate employees into } \\
\text { categories of high and low } \\
\text { performance. }\end{array}$ & $\begin{array}{l}\text { Does not separate employees } \\
\text { into categories of high and low } \\
\text { performance but rather } \\
\text { encourage all employees to } \\
\text { become high performers. }\end{array}$ \\
\hline Work climate & More competitive & More cooperative \\
\hline $\begin{array}{l}\text { Low } \\
\text { performers }\end{array}$ & $\begin{array}{l}\text { Are encouraged to leave the } \\
\text { organization and are replaced } \\
\text { with higher performers. }\end{array}$ & $\begin{array}{l}\text { Are encouraged to improve } \\
\text { performance and are given with } \\
\text { feedback to do so. }\end{array}$ \\
\hline
\end{tabular}

Source: developed by the author from material by Stewart and Brown, 2009

In general, merit-based systems are best suited to organizations pursuing differentiation strategies, while parity-based systems make sense for organizations using cost strategies (Stewart and Brown, 2009). Parity-based systems are perhaps more appropriate for public sector organizations.

\section{Concluding Summary}

The purpose of the paper was to present a synthesis in respect of Performance Appraisal (PA) by utilizing significantly the author's earlier published works based on theoretical as well as empirical studies in the area of PA. The impact of PA which is the essence of performance management on human development and institutional development has been theoretically and empirically well established. PA is very important in serving as (i) a summative function (to assist in making equitable and effective personnel decisions); (ii) a formative function (to improve employee current and future performance); and (iii) an informative function (a communication to the 
employee dealing with upward and downward communication for self development). A significant gap between what should be there and what exists is seen as per studies into practice of PA in Sri Lankan organisations. There is a highly felt need for developing a good PA system and implement it in a planned way. Essentially, as an agenda for action a 20-Point-Programme is presented as a general solution for the central question: how to develop a good PA system and implement it as planned. It was observed that the Point 17-Establish the practice that after PA, the evaluators always discuss with the employee through feedback interviews- is almost non-existent according to Sri Lankan practice, particularly in the public sector organizations. A prescriptive model of PA interview process is given providing a set of important guidelines to any manager who is supposed to conduct PA discussions. It is also possible to make PA strategic by emphasizing either merit-based systems or paritybased systems and linking merit and parity-based systems to business level strategy.

\section{References}

Aguinis H. (2007), Performance Management, PEARSON Education, New York.

Chruden H.J. and Sherman A.W. (1980), Personnel Management, South-Western Publishing Co., Ohio.

Dale B. and Cooper C. (1992), Total Quality and Human Resources: An Executive Guide, Blackwell Publishers, Oxford.

Dessler G. (1984), Personnel Management - Modern Concepts \& Techniques, Resfon Publishing Company, INC, Reston, Virginia.

Donnelly J.M., Gibson J.L. and Ivancevich J.M. (1984), Fundamentals of Management, $4^{\text {th }}$ ed, Business Publications, INC, Texas.

Edwards R.G. and Williams C.J. (1998), Performance appraisal in academic libraries: minor changes or major renovation?, Library Review, Vol.47, No.1, pp.14-19.

Farr J. (1998), Beat the Performance Review Blues, Restaurant Hospitality, Vol. 83, Iss. 9. Sep.

Goodale J.G. (1992), "Improving Performance Appraisal", Business Quarterly Vol.57, autumn, pp. 65-66.

Grote D. (2002), The performance appraisal question and answer book, AMACOM, New York.

Judge, T.A. and Ferris, G.R. (1993), Social Context of Performance Evaluation Decisions, Academy of Management, 36:1: pp. 80-105.

Kirkpatrick D.L. (1982), How to Improve Performance Through Appraisal and Coaching, AMACOM, New York.

Lepak D. and Gowan M. (2010), Human Resources Management: Managing employees for competitive advantage, PEARSON Education, New Jersey.

Maddux R.B. (1991), Effective Performance Appraisals, Kogan Page Ltd., London.

Mathis, R. L. and Jackson, J. H. (2000), Human Resources Management, $9^{\text {th }}$ ed, Cincinnati, Ohio: South-Western College Publishing.

Mithani, D.M. and Opatha, H.H.D.N.P. (2000), "Towards Effective Worker Performance Evaluation: An Important Issue for the New Millennium", NMIMS Management Review, XII:1, January-June, pp.39-50.

Morrisey G.L. (1983), Performance Appraisals in Business and Industry: Key to Effective Supervision, Addition Wesley Publishing Company, Reading.

Nemeroff W.F. and Cosentino J. (1979), Utilizing Feedback and Goal Setting to Increase Performance Appraisal Interviewer Skills of Managers, The Academy of Management Journal, Vol.22, No.3, pp. 566-576. 
Opatha, H.H.D.N.P. (1992) (Published in 1995), "An Assessment of Employee Performance Appraisal Practices of Selected State Corporations in Sri Lanka", Vidyodaya Journal of Social Science, Vol.6, No.1\&2, pp. 113-128.

Opatha, H.H.D.N.P. (2002), Performance Evaluation of Human Resources, Author Publication: Colombo.

Opatha, H.H.D.N.P. $\left(2003^{1}\right)$, "Employee Performance Evaluation Systems: An Evaluative Study of Selected Public Quoted Manufacturing Firms in Sri Lanka", Sabaragamuwa University Journal, Vol. 3: No 01, pp. 137-153.

Opatha, H.H.D.N.P. $\left(2003^{2}\right)$, "Job Performance Evaluation of Sri Lankan University Lecturer: An Agenda of Action and A Suggested Scheme", Vidyodaya Journal of Humanities and Social Science, Vol.1, pp. 59-87.

Opatha, H.H.D.N.P. (2005), "An Empirical Investigation of Union-related Factors Contributing to Labour-Management Relationship in Manufacturing Firms in Sri Lanka", Sasin Journal of Management, Sasin Graduate Institute of Business Administration of Chulalongkorn University, Vol. 11, No 1, pp.85102.

Opatha, H.H.D.N.P. $\left(2009^{1}\right)$, Towards a Performance Culture of Excellence in Sri Lanka by Performance Appraisal: An Agenda for Action, Abstracts of Symposium and Review Papers, 50 ${ }^{\text {th }}$ Anniversary Academic Conference, 10-12 December 2009, University of Sri Jayewardenepura, Sri Lanka.

Opatha, H.H.D.N.P. $\left(2009^{2}\right)$, Human Resource Management: Personnel, Department of HRM, University of Sri Jayewardenepura.

Opatha, H.H.D.N.P. and Hussain, Ali. (2008), "Performance Appraisal System and Business Performance: An Empirical Study in Sri Lankan Apparel Industry", Sri Lankan Journal of Human Resource Management, Journal of the Department of Human Resource Management, Faculty of Management Studies and Commerce, University of Sri Jayewardenepura, Vo.2 No 1, pp. 74-90.

Opatha, H.H.D.N.P. and Serasinghe D.K.S. (2011), "Human Resource Management Practices in Listed Firms in Sri Lanka", Sasin Journal of Management, Sasin Graduate Institute of Business Administration of Chulalongkorn University, Vol. 17, No 1, pp.18-35.

Rue L.W. and Byars L.L (1992), Management: Skills and Application, $6^{\text {th }}$ ed, IRWIN, Boston.

Rue L.W. and Byars L.L. (2004), Supervision, $8^{\text {th }}$ ed, Mc Graw Hill, Boston.

Schuler R.S. and Youngblood S.A. (1986), Effective Personnel Management, $2^{\text {nd }}$ ed, West Publishing Company, New York.

Stewart G.L. and Brown K.G. (2009), Human Resource Management: Linking Strategy to Practice, Jon Wiley \& Sons, Inc., New York.

Szilagyi A.D. (1981), Management and Performance, Goodyear Publishing Company, Inc., California.

Werther B.W., Davis K., Shwind H.F., Das H. and Miner F.C. (1985), Canadian Personnel Management and Human Resources, $2^{\text {nd }}$ ed, McGraw - Hill Ryerson Ltd., Toronto. 
Figure:1 Dimensions and Elements of Employee Performance Evaluation

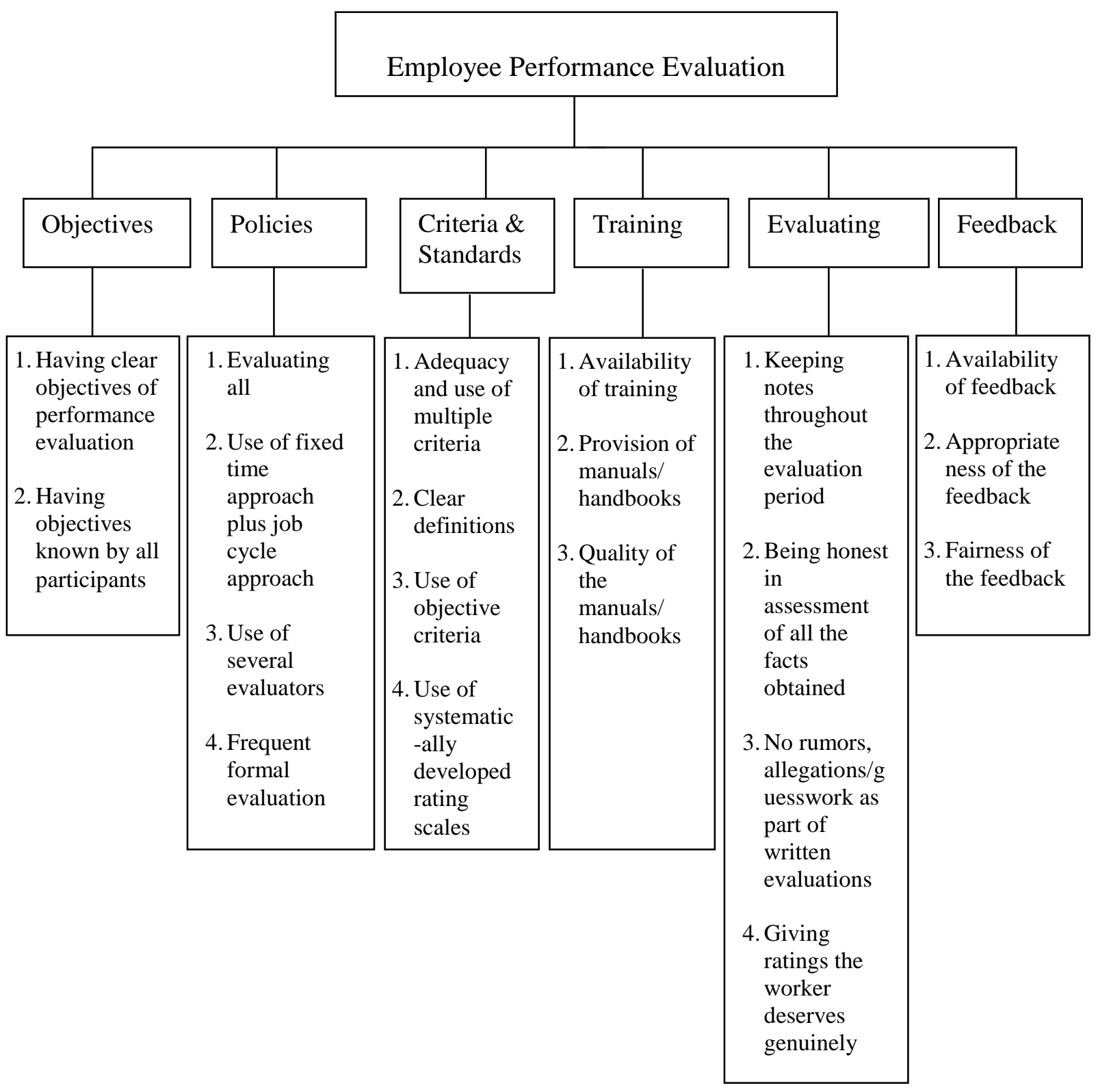

Source: Opatha $(2005,2012)$ 